Jurnal Homepage: http:/journal2.um.ac.id/index.php/jaa (p-ISSN: 2087-9695; e-ISSN: 2580-1015)

\title{
Real and accrual-based earnings management in Islamic Banks in Indonesia
}

\author{
Vega Wafaretta ${ }^{1}$, Nurika Restuningdiah ${ }^{1}$ \\ ${ }^{1}$ Universitas Negeri Malang, Jl. Semarang No. 5, Malang, Indonesia
}

\begin{abstract}
Diterima: 7 Mei 2020
Direvisi: 8 Juni 2020

Disetujui: 19 Juni 2020

Abstract

Koresponding:

Vega Wafaretta

vega.wafaretta.fe@um.ac.id

DOI:

http://dx.doi.org/10.17977/

um004v7i22020p91

Islamic banks have tendency to tinker the earnings to present positive income. Therefore, it requires the examination of the relationship between Real Earnings Management (REM) and Accrual-based Earnings Management (AEM) that have contribution in promoting earnings. There are 2 theories used including prospect theory is to explain the negative relationship between REM and AEM, and agency theory is to explain whether the variables can be costs of REM or AEM. There are 63 financial reports of Islamic banks during the 2013-2018 period are determined by using purposive sampling and gathered from the banks' website. Correlation and regression test were conducted. This study found that REM is done through generating operational revenue and reducing distributed revenue sharing beyond the normal activities. REM negatively affects AEM that managers will adjust AEM based on the results of REM during the financial period. These findings confirm the prospect theory when the realized income is less than profit expectation, managers will employ accrual manipulation with the motive of prospect theory to achieve income target. Market share is found as a cost of AEM and institutional shows different result which drives REM more. The implication of this study is to provide findings how Islamic banks engage in earnings management. The relationship between REM and AEM shows the reliability of earnings that needs concern to restrict.

Keywords: Accrual-Based Earnings Management (AEM); Real Earnings Management (REM); Variables Costs
\end{abstract}

\section{INTRODUCTION}

Management engagement in earnings management can be due to several reasons. It arises from debt contract, political reason, or conflicting of interest between managers and principal. Managers commonly have personal reason to achieve bonus by manipulating earnings, both through Real Earnings Management (REM) through real activities and Accrual-based Earnings Management (AEM) (Shen \& Chih, 2005). In bank context, REM is applied by accelerating the loan, managing the interest expense paid and (or) postponing discretionary expenses to jack up profits (Roychowdhury, 2006; Surifah, 2014). Meanwhile, AEM is done by selecting accounting policies which affects income and expenses in income statement and cash in/out in statement of cash flows (Scott, 2012).

However, there are other reasons why management implement earnings management, especially Islamic banks which have different characteristics from conventional banks. Business financed by the Islamic banks that have high uncertainty and banks have to bear additional risks due to the margin and profit loss sharing contracts (Hamdi \& Zarai, 2012). Besides, Islamic banks are still new compared to conventional banks. Islamic banks attempt to fulfill industry expectations, especially to preserve depositors' trust (Shen \& Chih, 2005). To maintain depositors' trust and to attract new depositors, Islamic banks manage the earnings to present positive income or achieve the income threshold (Hamdi \& Zarai, 2012).

Efforts to meet income benchmark is very important because earnings are the key concerned by stakeholders. Managing earnings might enhance the reputation for stakeholders (Graham et al., 2005) especially depositors. Management's action is to attain current year income and give a signal to have better performance in the next period (Gunny, 2010). It can be observed that mostly earnings of Islamic banks in Indonesia always meet the prior year's earnings. These facts indicate that the fundamental characteristics of Islamic financial institution do not restrict managers to manage earnings. Islamic banks are not much different from conventional in cultivating profit although Islamic banks have less practices of earnings management than non-Islamic banks (Quttainah et al., 2011). 
Many existing studies have examined that Islamic banks do earnings management by accrual adjustments or accounting practice artificially as mentioned by Saringat et al. (2013) for instance by avoiding loss and eluding earnings decrease (Hamdi \& Zarai, 2012), using abnormal loan loss provisions (Quttainah et al., 2011), or smoothing the income (Saringat et al., 2013). Other study found that earning management in Islamic banks is also conducted by real activities (Surifah, 2014). However, prior studies examined REM and AEM in Islamic banks separately. It is needed to examine the relationship of both strategies of earnings management simultaneously in this study.

Investigation of management's preferences between REM and AEM become a concern in recent research (Vladu, 2015). Several studies present findings how REM and AEM strategies correlate in firms (Zang, 2012; Jafarpour \& Soumehsaraei, 2013). Zang (2012) found there was a trade-off between 2 methods. Some studies provide the same evidence but in specific context such as in seasoned equity offerings as a cost constraining accrual and encouraging real manipulation (Cohen \& Zarowin, 2010; Kothari et al., 2016), tighter accounting standards that significantly increase REM (Ewert \& Wagenhofer, 2005), duration of firm overvaluation (Badertscher, 2011), in the Initial Public Offering (IPO) year (Chung et al., 2012) or Sarbanes-Oxley periods (Cohen et al., 2008; Ibrahim et al., 2011).

Contrary to Zang (2012), Jafarpour \& Soumehsaraei (2013) found that management conduct REM and AEM complementary each other. Due to the different findings of the correlation between REM and AEM, it is important to establish additional study in testing how these 2 earnings managements correlate in Islamic banks. The examination of the correlation between REM and AEM at the same time can show the overall impact of earnings management activities and how managers utilize these 2 strategies with different costs and timing. Besides, REM and AEM in Islamic banks are slightly different. Related to REM, revenue of Islamic banks origins from Islamic-based contracts, such as murabaha, istishna, salam, ijarah, mudharabah, or musharaka; and interest expense in conventional banks is replaced by revenue sharing to third parties as the Islamic banks do not give interest to depositors, but in the form of revenue sharing (Surifah, 2017).

This study fills the gap and makes contributions in several ways. Firstly, this study is an initial study to examine the relationship between REM and AEM in Islamic banks context. It focuses on both techniques at a time because prior studies examine only one type of earnings management (Quttainah et al., 2011; Saringat et al., 2013; Surifah, 2014). Secondly, it also improves the one part of the formula to calculate REM which is measured by revenue sharing distributed. Revenue sharing distributed is one of specific variable for Islamic bank context, which is different with interest expense paid to conventional bank customers. To reflect the real manipulation, the amount of revenue sharing should be in cash. The reason could be revenue sharing to third parties is an expense that can be managed. It can be different with the revenue sharing paid in cash. Similar to abnormal cash flows that be regressed with accrual operating revenue, the sharing distribution should be in cash that will be regressed with accrual operating revenue. It supports a statement that states abnormal cash flows is a sign of earnings management (Srivastava, 2019). Therefore, the revenue sharing distributed in income loss statement should be deducted by unpaid revenue sharing. Thirdly, it attempts to explain the relationship between REM and AEM using prospect theory. Prospect theory has been used to explain earnings management (Koonce \& Mercer, 2005; Pududu \& Villiers, 2016), but the real and accrual methods has not been discussed at the same time. Therefore, this study aims to test the correlation between REM and AEM in Islamic banks whether there is a trade-off or complimentary association.

This study also examines the relative costs effects on REM and AEM whether to encourage or limit REM or AEM using agency theory. When the relative costs limit 1 technique, the banks will engage more in other techniques. Some studies have found that there are relative costs that affect the selection between REM and AEM (Zang, 2012; Joosten, 2012). This study does not test on a specific event due to recently evolving of Islamic banks in Indonesia in the last 10 years. This study aims to optimize the results, so that it uses all annually Islamic banks' financial statements available from 2013 to 2018. Actually, there are several banks founded in 2011, but financial statements of 2011 were used to give data $\mathrm{t}-2$ for samples of 2013 .

\section{Prospect Theory}

Prospect theory defines several postulates. Certainty effect is related to choices to take or avoid risks based on certainty of gains or losses. The theory explains that the individual decision is based on risks and prospects. The risks will be avoided if there is a certainty of returns. When the realized income has been over the expectation, hence individual will be a risk averter (Kahneman \& Tversky, 1979). Otherwise, if there is a certain loss, so individual will be a risk taker to gain income (Shen \& Chih, 2005). 
Prospect theory then start to be used to explain the incentives of and to predict earnings management behavior (Shen \& Chih, 2005; Li \& Hwang, 2017; Subekti, 2012). When corporates encounter gain or loss in capital market, corporate management will take actions in responding the gain or loss by engaging in earnings management to increase income (Li \& Hwang, 2017). The individual will derive the maximum value on the loss (not profit). The condition of small loss or negative earnings will motivate managers to perform earnings management to change negative earnings to positive earnings (Subekti, 2012).

Despite effort to change from negative to positive earnings, managers might have income target as a reference point. If the realized income is below the target, individual will take opportunities to increase the income (Kahneman \& Tversky, 1979; Fiegenbaum, 1990; Bowman, 1980). In short, managers focus on achieving earnings target as the theory states that determination of an outcome to be classified as gains or losses is based on a flexible reference point (Pududu \& Villiers, 2016).

This threshold point can be adjusted based on investors', creditors', or analysts' expectations as basis to evaluate firms' performance (Koonce \& Mercer, 2005; Degeorge et al., 1999). Reference point can be zero, earnings in prior year or analysts' forecast (Degeorge et al., 1999). The reference point can push firms to either avoid small losses, take big baths, create a reserve, or consider investors' point of reference. That is why prospect theory explains the reason of managers to avoid reporting losses (Koonce \& Mercer, 2005). After reference point is decided, then decision maker specifies that earnings is more than reference point (Koonce \& Mercer, 2005).

After all, individual likes to maintain health, so that it determines the threshold as minimum wealth to achieve (Pududu \& Villiers, 2016). Therefore, prospect theory is used to explain the relationship between REM and AEM whereas management uses AEM and REM to maintain the wealth or income target. Referring to Subekti (2012), the negative earnings from REM will motivate managers to perform AEM with many reasons, such as to change from negative to positive income or to achieve particular income target.

\section{Agency Theory}

Agency theory begins with an agency relationship between manager as an agent and shareholders as principals (Jensen \& Meckling, 1976). There is a separation between shareholders and management that manager should ideally act on behalf of shareholders. This separation could lead to problems or not based on 2 views from stewardship or agency theory (Bjurman \& Weuhagen, 2013). If the management act as steward, action will be executed in accordance with the shareholders' sake. This behavior does not lead to problems because managers satisfy the shareholders as stated by stewardship theory.

Otherwise, the problems arise when managers have self-interest and neglect the shareholders' will. Managers act for their own sake and motives, not for shareholders' interests which is then explained by agency theory (Tanjung et al., 2015; Kazemian \& Sanusi, 2015). There is one form of the agency conflict is by doing earnings management to window dress the financial statements (Hermiyetti \& Manik, 2012). The motives of earnings management could be the achievement of income target to smooth the income.

Agency theory suggests that monitoring mechanisms are required to align the shareholders and management interest. The possible mechanisms are board, ownership structure, and financial capability such as capital (Kazemian \& Sanusi, 2015) to restrict earnings management. The explanation on how these 3 mechanisms limiting of which earnings management between REM or AEM is explained below in the hypothesis development section.

\section{Earnings Management}

The main drivers of earnings management are capital market incentives, contract incentives and regulatory incentives. Firms face capital market incentives in several settings such as beating threshold, issuing stocks, mergers, or insider trading (Eisele, 2012). This study focuses on earnings management to beat benchmarks through 2 methods of earnings management, real, and accrual.

AEM is related to choose accounting methods and estimates. The difference of AEM from REM is accrual judgement doesn't have a direct impact on cash flow. AEM covers determining depreciation and impairment method for property, plant, and equipment; allowance for loan losses/ doubtful, inventory capitalization cost and allowances; fair value and impairment consideration for the financial instrument (Eisele, 2012; Zang, 2012). AEM also involves the choosing of time in applying accounting principles (Stolowy \& Breton, 2000). 
Meanwhile, REM is manipulation of managers' real action that deviates from normal practice (Cohen \& Zarowin, 2010). It modifies the structuring of operation, investment, or financing activities and timing of those activities only to affect earnings (Roychowdhury, 2006; Ewert \& Wagenhofer, 2005). It is hard to be detected and not being concerned by auditors, regulators, and investor; whereas real manipulations have severe impacts on cash flow and future performance (Cohen \& Zarowin, 2010; Kothari et al., 2016). Real action involved makes it more costly and difficult to be restricted than AEM (Ewert \& Wagenhofer, 2005).

In order to upward earnings, the company can engage in REM by accelerating sales with high discounts, changing the schedule of goods delivery, and postponing or reducing expenditures for instance research and development, training, and maintenance (Roychowdhury, 2006). Otherwise, if the company is willing to delay earnings, so actions not cutting sales price and accelerating costs might be chosen (Degeorge et al., 1999).

In banking context, the most popular method is using accrual loan loss provisions (Agarwal, 2007). However, real manipulation could also be done by banks through managing the revenue or expense. Related to revenue, management conduct the real action indicated by abnormal cash flows which is different from the normal activities (Surifah, 2017; Chou \& Chan, 2018), using commission and fee income taken by financial institution from account charges to customers and managing other kinds of charges fees. Commission and fee income can be jacked up or detained by increasing or decreasing the numbers of loan and other banks products (Ozili \& Outa, 2019; Ozili, 2017; Agarwal, 2007). Related to expense, bank can arrange the interest expense based on management decision and accelerate or postpone discretionary expenses (research and development, advertising general and administration expenses, replacement cost of production assets, and allowance for doubtful accounts) to maintain the income target (Surifah, 2017; Chou \& Chan, 2018).

Other methods can be in the form of executing or postponing sale of securities to record realized gain or loss (Beatty et al., 2002; Barth et al., 2017; Agarwal, 2007). In Islamic banks context, there are adjustments of accounts and banks products from conventional banks, such as structuring the operation income from Islamic products, managing revenue sharing distribution as a replacement for interest expense, and fiddling discretionary expenses (Surifah, 2014).

\section{Previous Studies}

There are 2 patterns of earnings management found in previous studies. The first finding is REM and AEM are the trade-off as substitutes. The higher (lower) cost of AEM will decrease (increase) AEM and increase (decrease) REM. Otherwise, the higher (lower) cost of REM will decrease (increase) REM and increase (decrease) AEM (Zang, 2012; Joosten, 2012).

The choice between REM and AEM depends on relative costs. An action to determine which type of earnings management can be based on the amount of the relative cost (Zang, 2012). Badertscher (2011) stated that firms with financial distress and high possibility of bankrupt are less in doing in REM. Zang (2012) found that market share and financial health negatively affect AEM, and institutional ownership positively affects AEM.

The second finding is REM and AEM are complementary. Jafarpour \& Soumehsaraei (2013) found that REM and AEM are used simultaneously to smooth income. The 2 strategies can be used to achieve one objective which is income target. One of the findings is management manage both abnormal cash flow from operation as real manipulation and discretionary accruals as accrual upward (Vladu, 2015).

\section{Hypothesis Development}

The relation between 2 methods of earnings management is hypothetically negative as the negative relation between return achieved and risk preference of the managers explained by prospect theory. Stolowy \& Breton (2000) stated that earnings management is applied to influence market perception related to the risk of the firms, consists of risk associated with variance of return through earning per share and risk associated with financial structure through debt to equity ratio. Market perceive risk is related to unstable or unexpected low earnings. Therefore, when income has failed to attain the target, managers are assumed to be risk taker by applying AEM.

AEM will direct market perception and result in higher risk as indicated by reporting lower reliability of earnings. In other words, it is riskier to solely engage in AEM. If the income is far below the threshold and all strategies of accrual have been used, there will be no option available to push additional income (Cohen \& Zarowin, 2010). 
Although Jafarpour \& Soumehsaraei (2013) found the different results which real manipulation positively affects AEM, the hypothesis developed is that accrual is negatively correlated with REM (Zang, 2012; Joosten, 2012). REM and AEM have different timing. Real manipulation (REM) is conducted during the period as it is impossible to be executed at the end of the year. AEM is the next step after realizing REM which is done at the end of the year. REM is applied during the operating of the banks and before the year end. Otherwise, AEM is implemented after the completion of activities during a year, but before the announcement of financial statements. Managers are found adjusting the level of AEM according to REM (Zang, 2012). If REM results are unexpectedly high (low), the managers will decrease (increase) the level of AEM. Managers will adjust the income from real operation through AEM (Zang, 2012; Joosten, 2012).

Farook et al. (2014) also found overall results that REM indicated by profit distribution (sharing) has an inverse relationship with AEM measured by loan loss provision. These incentives may be caused by the inability of banks to use real choices to smooth earnings. Managers will use accrual to cover the shortcomings to achieve the income target. It is aligned with prospect theory explanation that managers focus on earnings target (Koonce \& Mercer, 2005). The negative relationship between real and accrual means that managers avoid to report too large earnings, but only achieve sufficient gains from reference point. Therefore, the hypothesis developed is as follows:

$\mathrm{H}_{1}$ : Real earnings management negatively affects accrual earnings management.

Employing earnings management needs cost, whereas AEM is less costly than REM. Based on substitution hypothesis between REM and AEM, when the cost of REM increases, for example in accelerating sales/loans, it signifies that low REM and management will use more AEM to achieve income target. The mechanism of variables as costs that limit earnings management will be explained by agency theory. To align with prospect theory that predict negative relationship between REM and AEM, the hypothesis is when a variable is a cost that decrease REM, this variable will increase AEM. Hereby the hypothesis of how several variables might be costs of AEM or REM.

Audit quality is one of cost of AEM. Management has obligation to pay audit fee whereas audit quality can control AEM. One indicator of audit quality is audited by big-4 accounting firms which reflects the better audit than nonbig-4 accounting firms. There are mixed findings about the relationship between audit quality and earnings management. The positive and negative value is based on the different condition. However, agency theory predicts negative relationship. Audit has significant role to reduce AEM (Hermiyetti \& Manik, 2012). The higher of audit quality has impact on the easier of auditor to detect AEM because auditors have higher possibility to discover the unusual accrual judgment. Auditors have to ensure that real transactions are properly recorded, but have no obligation in evaluating managers' motivation in applying those real activities (Burnett et al., 2012). Aligned with prospect theory that states negative relationship between AEM and REM, AEM will be avoided because it can be detected by auditor, but REM is employed more (Cohen \& Zarowin, 2010). The hypothesis developed is as follow:

$\mathrm{H}_{2 \mathrm{a}}$ : Audit quality negatively affects accrual earnings management.

Financial health is a cost of AEM. The attainment of financial health demands on cost and this financial health further might benefit management. Banks with good financial health have wide opportunities to engage in real manipulation (Badertscher, 2011) and require nonprofit support through AEM. Otherwise, unhealthy banks need improvement in financial performance through AEM because those banks incapable to employ REM (Wasiuzzaman, 2018; Zang, 2012). This different impact of financial health on AEM and REM is in accordance with the negative relationship between AEM and REM as stated by prospect theory. Therefore, the hypothesis developed is as follow: $\mathrm{H}_{2 \mathrm{~b}}$ : Financial health negatively affects accrual earnings management.

Market share is a cost of AEM. Management needs cost and efforts to increase market share which the market share provides more advantages. Banks that dominate the markets enjoy the competitive advantages due to their experiences, economic benefits, and better power on customers (Wasiuzzaman, 2018). These banks do not need to increase income through AEM (Zang, 2012) because the income target through real activities have been achieved. Otherwise, banks that encounter competitive pressure will have less competitive advantages. According to prospect theory which predict negative relationship between REM and AEM, banks with low market share will have high incentives to implement AEM because REM is difficult to implement (Joosten, 2012). The hypothesis developed is as follow:

$\mathrm{H}_{2 \mathrm{c}}$ : Market share negatively affects accrual earnings management.

Institutional ownership is a cost that can limit REM as one kind of control mechanism. The institutional ownership becomes a cost because management needs costs to employ institutional investors to monitor decision making (Tanjung et al., 2015). Based on agency theory, institutional 
investors are concern in monitoring real activities with the aim of focusing strategies that have consequences in the long term (Zang, 2012). It therefore, higher institutional ownership will limit management in employing REM. Management should avoid using real activities such as increasing income for short term target that will sacrifice long term purpose. Accordingly, the involvement of institutional investors will control REM which leads to lower REM and higher AEM (Zang, 2012). The impact of institutional ownership on REM and AEM is different as the negative relationship between REM and AEM by prospect theory. The hypothesis developed is as follow:

$\mathrm{H}_{3}$ : Institutional ownership negatively affects real earnings management.

\section{Methodology}

This study focuses on Islamic Banks and excludes Islamic-window banks due to Islamic-window banks are only business units from parent conventional banks, which have operation based on Islamic principles. Islamic-window banks have different characteristics and obtain financial influences from conventional core business. Because this study focuses on Islamic banks, the population is 75 financial statements from 13 Islamic banks from 2013-2018. There were only 11 banks tested because the 2 Islamic banks have just operated in last 5 years. The period of 2013-2018 is chosen based on the length of the operation years and data available for $t, t-1$, and $t-2$ required. The detail sampling procedures is shown on Table 1 in the results section.

Data used in this study is secondary data of annual reports collected from the website of the Islamic banks. Annual financial statement is used due to an observation of REM and AEM to be more appropriate if they are examined on an annual basis. The use of AEM can be observed in the year end.

AEM is measured by discretionary accrual referring to Roychowdhury (2006) and Zang (2012) which is adjusted to Islamic banks' account. Discretionary accruals are the residual as the difference between actual accruals and the normal predicted. Residual value is generated from the regression as follows:

$$
\frac{\text { Accruals }_{i t}}{A_{\mathrm{it}-1}}=\alpha_{0}+\alpha_{1}\left(\frac{1}{A_{\mathrm{it}-1}}\right)+\beta_{1}\left(\frac{\Delta \mathrm{OR}_{\mathrm{it}}}{\mathrm{A}_{\mathrm{it}-1}}\right)+\beta_{2}\left(\frac{\text { PPE }_{\mathrm{it}-1}}{\mathrm{~A}_{\mathrm{it}-1}}\right)+\varepsilon_{\mathrm{it}}
$$

Note:

Accruals ${ }_{\text {it }} / \mathrm{A}_{\mathrm{it}-1}$

$\alpha_{1}\left(1 / \mathrm{A}_{\mathrm{it}-1}\right)$

$\Delta \mathrm{OR}_{\mathrm{it}} / \mathrm{A}_{\mathrm{it}-1}$

$\mathrm{PPE}_{\mathrm{it}-1} / \mathrm{A}_{\mathrm{it}-1}$

$\alpha_{0}$

$\varepsilon_{\text {it }}^{0}$

: Earnings before extraordinary items and discontinued operations minus cash flow from operation of bank $i$, in the year $t$, which are scaled with total assets in the year $\mathrm{t}-1$.

: Interception scaled with total assets of bank $\mathrm{i}$, in the year $\mathrm{t}-1$ thus operating cash flow does not have value 0 when operating revenue and lag operating revenue value are 0 .

: Operating revenue of bank $i$, in the year $t$, minus operating revenue of bank $\mathrm{i}$ in the year $\mathrm{t}-1$, which are scaled with total assets in year $\mathrm{t}-1$.

: Plant, property, and equipment gross of bank $\mathrm{i}$, in the year $\mathrm{t}-1$, which are scaled with total assets in the year $\mathrm{t}-1$.

: constant.

: error term of bank $\mathrm{i}$, in the year $\mathrm{t}$

Real manipulation (REM) includes abnormal level of production costs and abnormal level of discretionary expenditures (Zang, 2012; Joosten, 2012). REM for conventional banks is measured referring to Surifah (2017) and Chou \& Chan (2018) which consists of abnormal interest expense, abnormal discretionary expense, and abnormal cash flows.

REM for Islamic banks is a modification from REM of conventional banks based on the specific products and accounts of Islamic banks. One proxy of REM for Islamic banks is modification of abnormal production cost in manufacturing companies into abnormal revenue sharing distributed (Surifah, 2014). It is due to the cost of sales in banking institution is interest expense paid to depositors, which is revenue sharing distributed to depositors in Islamic banks. Therefore, REM measurement consists of 3 proxies, namely the abnormal cash flow of the operation activities, abnormal revenue sharing distributed, and abnormal discretionary expenses whereas the abnormal is the difference between actual and the normal cash flow of the operation activities, actual and normal revenue sharing distributed expenses or actual and normal discretionary expenses. The abnormal cash flow from operation $\left(\mathrm{REM}_{\mathrm{CFO}}\right)$, abnormal revenue sharing $\left(\mathrm{REM}_{\mathrm{RSD}}\right)$ and abnormal discretionary expenses $\left(\mathrm{REM}_{\mathrm{DE}}\right)$ are residual generated from the regression of 2,3 , and 4 , respectively as follow: 


$$
\begin{aligned}
& \frac{\mathrm{CFO}_{\mathrm{it}}}{\mathrm{A}_{\mathrm{it}-1}}=\alpha_{0}+\alpha_{1}\left(\frac{1}{\mathrm{~A}_{\mathrm{it}-1}}\right)+\beta_{1}\left(\frac{\mathrm{OR}}{\mathrm{A}_{\mathrm{it}-1}}\right)+\beta_{2}\left(\frac{\Delta \mathrm{OR}}{\mathrm{A}_{\mathrm{it}-1}}\right)+\varepsilon_{\mathrm{it}} \\
& \frac{\left(\mathrm{RSD}_{\mathrm{it}}-\text { Unpaid Rev Sharing }\right)}{\mathrm{A}_{\mathrm{it}-1}}=\alpha_{0}+\alpha_{1}\left(\frac{1}{\mathrm{~A}_{\mathrm{it}-1}}\right)+\beta_{1}\left(\frac{\mathrm{OR}_{\mathrm{it}}}{\mathrm{A}_{\mathrm{it}-1}}\right)+\beta_{2}\left(\frac{\Delta \mathrm{OR}_{\mathrm{it}}}{\mathrm{A}_{\mathrm{it}-1}}\right)+\beta_{3}\left(\frac{\Delta \mathrm{OR}_{\mathrm{it}-1}}{\mathrm{~A}_{\mathrm{it}-1}}\right)+\varepsilon_{\mathrm{it}} \\
& \frac{\mathrm{DE}}{\mathrm{A}_{\mathrm{it}-1}}=\alpha_{0}+\alpha_{1}\left(\frac{1}{\mathrm{~A}_{\mathrm{it}-1}}\right)+\beta\left(\frac{\mathrm{OR}_{\mathrm{it}-1}}{\mathrm{~A}_{\mathrm{it}-1}}\right)+\varepsilon_{\mathrm{it}}
\end{aligned}
$$

Note:

$\mathrm{CFO}_{\mathrm{i} t} / \mathrm{A}_{\mathrm{it}-1}$
$\alpha_{1}\left(1 / \mathrm{A}_{\mathrm{it}-1}\right)$
$\mathrm{OR}_{\mathrm{i} /} / \mathrm{A}_{\mathrm{it}-1}$
$\Delta \mathrm{OR}_{\mathrm{i}} / \mathrm{A}_{\mathrm{it}-1}$
$\left(\mathrm{RSD}_{\mathrm{it}}-\right.$ Unpaid Rev Sharing $) / \mathrm{A}_{\mathrm{it}-1}$
$\Delta \mathrm{OR}_{\mathrm{it}-1} / \mathrm{A}_{\mathrm{it}-1}$
$\mathrm{DEit} / \mathrm{Ait}-1$
$\mathrm{OR}_{\mathrm{it}-1 / 1} \mathrm{~A}_{\mathrm{it}-1}$
$\alpha_{0}$
$\varepsilon_{\mathrm{it}}$

: Cash flows from operations of bank $i$, in the year $t$, which are scaled with total assets in the year $\mathrm{t}-1$.

: Interception scaled with total assets of bank $\mathrm{i}$, in the year $\mathrm{t}-1$ thus operating cash flow does not have value 0 when operating revenue and lag operating revenue value are 0 .

: Operating revenue of bank $i$, in the year $t$, which are scaled with total assets in the year $\mathrm{t}-1$.

: Operating revenue of bank $i$, in the year $t$, minus operating revenue of bank $i$ in the year $t-1$, which are scaled with total assets in year $\mathrm{t}-1$.

: Revenue sharing distributed for an investor of an unrestricted investment in income loss statement deducted by unpaid revenue sharing of bank $i$, in the year $t$, which are scaled with total assets in the year $\mathrm{t}-1$.

: Operating revenue of bank $\mathrm{i}$, in the year $\mathrm{t}-1$, minus operating revenue of bank $\mathrm{i}$ in the year $\mathrm{t}-2$, which are scaled with total assets in year $\mathrm{t}-1$.

: Discretionary expenses of bank $i$, in the year $t$, which are scaled with total assets in the year $\mathrm{t}-1$.

: Operating revenue of bank $\mathrm{i}$, in the year $\mathrm{t}-1$, which are scaled with total assets in year $\mathrm{t}-1$.

: constant.

: error term of bank $\mathrm{i}$, in the year $\mathrm{t}$.

In the term of the actual value of revenue sharing distributed or discretionary expenses are lower than normal value, the abnormal revenue sharing distributed and abnormal discretionary expense will be negative. Negative abnormal cost indicates upward earning management. Therefore, estimated residuals from the estimation model of revenue sharing distributed and discretionary expenses are multiplied by -1 , so that higher positive values of estimated residuals indicates the reduction of costs and higher upward earning management (Joosten, 2012).

After each REM measurement is calculated, then total REM will be counted, like Joosten (2012) stated that accumulated all the 3 REM proxies and Zang (2012) that added up REM of production cost and REM of discretionary expenses. This study will sum up those 3 proxies of REM, REM ${ }_{\text {CFO, }}$ $\mathrm{REM}_{\mathrm{RSD}}$, and REM ${ }_{\mathrm{DE}}$ to obtain the total REM. The total REM will represent the accumulation of real manipulation from cash flows, revenue sharing distributed, and discretionary expenses. For example, if the cash flows managed is upward, revenue sharing is managed upward, and discretionary expenses are pressed to support upward earnings. Therefore these 3 activities will support each other to upward the earnings.

Besides the measurement of REM and AEM, there are 4 explanatory variables; 3 costs that limit $\mathrm{AEM}$, for instance audit quality, financial health, and market share; and 1 cost that limits REM such as institutional ownership. Audit quality is measured by whether banks are audited by the Big 4 which is 1 if banks are audited by Big4 and 0 otherwise (Joosten, 2012). Financial health is measured by cash flow-to-total debts (Beaver, 1966). Market share is measured referring to Rettab et al. (2010) which is adjusted as banks' revenue to the total revenue of its Islamic banking industry. Institutional ownership is measured by a percentage of institutional ownership at the beginning of year t (Zang, 2012). 
There are some control variables including Return on Assets (ROA), size, and leverage that are generally used to control the different performance and size. Size is measured by log of total assets (Zang, 2012) and leverage is measured by total liabilities to total assets (Cohen et al., 2008).

A correlation test is conducted to test the hypothesis 1 about the relationship between REM and AEM. A regression test is done based on formula 5 and 6 to examine hypothesis $2 \mathrm{a}, 2 \mathrm{~b}, 2 \mathrm{c}$, and 3 about the impact of relative costs on earnings management. Audit quality, financial health, and market share are costs of AEM whereas these variables can minimize the AEM, otherwise positively affect REM. Meanwhile, beginning institutional ownership is cost of REM which external control can minimize REM, but positively affects AEM. The regression estimations are as follow:

$$
\begin{aligned}
& \text { REM }_{\mathrm{t}}=\alpha_{0}+\beta_{1} \text { AudQual }+\beta_{2} \text { FinHealth }+\beta_{3} \text { MarketShare }+\beta_{4} \text { InsOwn }+\beta_{5} \text { ROA }+\beta_{6} \text { Size } \\
& +\beta_{7} \text { Leverage }+\varepsilon_{\text {it }} \\
& \mathrm{AEM}_{\mathrm{t}}=\alpha_{0}+\beta_{1} \text { AudQual }+\beta_{2} \text { FinHealth }+\beta_{3} \text { MarketShare }+\beta_{4} \text { InsOwn }+\beta_{5} \mathrm{ROA}+\beta_{6} \text { Size } \\
& +\beta_{7} \text { Leverage }+\varepsilon_{\text {it }}
\end{aligned}
$$

Dependent variable in formula 5 is REM which is sum of abnormal cash flow from operation $\left(\mathrm{REM}_{\mathrm{CFO}}\right)$, abnormal revenue sharing $\left(\mathrm{REM}_{\mathrm{RSD}}\right)$, and abnormal discretionary expenses $\left(\mathrm{REM}_{\mathrm{DE}}\right)$. It is due to REM is done through the combination of those 3 proxies. Actually, formula 5 and 6 are similar. This study test formula 5 and 6 as robustness to ensure the consistent results. For example, if audit quality has positive impact on REM (in formula 5), it should have negative impact on AEM (in formula 6). This study conducted correlation and regression tests using EViews 8.

\section{RESULTS AND DISCUSSION}

\section{Goodness of Fit}

Initially, the number of financial statements of Islamic banks from 2013 to 2018 is amounted to 75 because there are 2 banks that have operated less than 6 years. After excluding banks with uncomplete data, there are 66 samples consisting of 11 banks in the period of 2013-2018. To fulfill the goodness of fit, there are 3 outliers excluded which are number 10, 51, and 60. Therefore, 63 samples are tested for correlation and regression. The number of samples is shown on Table 1.

The goodness of fit is shown on Table 2 below. The table compares the goodness of fit between before and after excluding outliers. Before excluding outliers by using 66 samples, the data still contains autocorrelation, non-normality, and heteroskedasticity. After excluding outliers by using 63 samples, the data fulfills all criteria of goodness of fit for both AEM and REM equation. Durbin Watson scores show that there is no autocorrelation. Prob. Jarque-Bera scores which are more than 0.05 mean the normality is fulfilled. Prob. Breusch-Pagan-Godfrey scores of more than 0.05 shows the homoskedasticity. Lastly, the data fulfills non-multicollinearity.

\section{Descriptive Data}

Descriptive data of earnings management and firms' characteristics variables are shown on Table 3 and Table 4 . Based on Table 3, the positive mean value of $\mathrm{REM}_{\mathrm{CFO}}$ amounted to 0.00031 indicates that Islamic banks tend to do upward REM through abnormal cash flow of the operation. In the other words, Islamic banks increase the earnings through generating more revenue from operating activities. The negative mean value of $\mathrm{REM}_{\mathrm{RSD}}$ amounted to -0.00041 indicates that Islamic banks tend to do downward REM or decrease earnings through revenue sharing distributed. Islamic banks smooth the revenue distribution to depositors (Hamdi \& Zarai, 2013) by slightly increasing revenue sharing distribution to decrease earnings. This high revenue sharing distributed indicates that Islamic banks have concern to satisfy the depositors through revenue sharing distribution. The positive mean value of $\mathrm{REM}_{\mathrm{DE}}$ amounted to 0.00043 means there

Table 1. Number of Samples Tested

\begin{tabular}{lc}
\multicolumn{1}{c}{ Description } & Total \\
\hline The number of financial statements from 2013-2018 (13 Islamic banks) & 75 \\
Banks with uncomplete data for 2011-2012 (2 Islamic banks) & 9 \\
The number of samples from 2013-2018 (6 years, 11 Islamic banks) & 66 \\
Outlier (data number 10, 51, 60) & 3 \\
The number of samples tested & 63 \\
\hline
\end{tabular}


Table 2. Goodness of Fit

\begin{tabular}{lcccc} 
& \multicolumn{2}{c}{ Before Excluding Outlier $(\mathrm{n}=66)$} & \multicolumn{2}{c}{ After Excluding Outlier (n=63) } \\
\hline & AEM Equation & REM Equation & AEM Equation & REM Equation \\
\hline $\begin{array}{l}\text { Non-autocorrelation Test } \\
\text { (Durbin-Watson) }\end{array}$ & 1.699 & 1.735 & 1.890 & 1.921 \\
$\begin{array}{l}\text { Normality Test } \\
\text { (Prob. Jarque-Bera) }\end{array}$ & 0.000 & 0.162 & 0.391 & 0.829 \\
Homoskedasticity & & & & \\
(Prob. Breusch-Pagan-Godfrey) & 0.008 & 0.000 & 0.107 & 0.063 \\
Non-multicollinearity Test & & & & \\
VIF: & 1.453 & 1.453 & 1.470 & 1.470 \\
Audit Quality & 1.180 & 1.180 & 1.141 & 1.141 \\
Financial Health & 5.210 & 5.210 & 5.456 & 5.456 \\
Market Share & 1.196 & 1.196 & 1.195 & 1.195 \\
Institutional Ownership & 1.340 & 1.340 & 1.258 & 1.258 \\
ROA & 5.746 & 5.746 & 5.962 & 5.962 \\
Size & 1.363 & 1.363 & 1.383 & 1.383 \\
Leverage & & & & \\
\hline
\end{tabular}

Table 3. Descriptive Data of Earnings Management

\begin{tabular}{lllll}
\hline \multicolumn{1}{c}{$\begin{array}{c}\text { Earnings } \\
\text { Management }\end{array}$} & N & Min. & Max. & Mean \\
\hline $\mathrm{REM}_{\mathrm{CFO}}$ & 63 & -0.164 & 0.139 & 0.00031 \\
$\mathrm{REM}_{\mathrm{RSD}}$ & 63 & -0.032 & 0.034 & -0.00041 \\
$\mathrm{REM}_{\mathrm{DE}}$ & 63 & -0.255 & 0.114 & 0.00043 \\
$\mathrm{REM}$ & 63 & -0.218 & 0.279 & 0.00033 \\
$\mathrm{AEM}$ & 63 & -0.158 & 0.176 & -0.00041 \\
\hline
\end{tabular}

Note: REM is real earnings management which is the sum of $\mathrm{REM}_{\mathrm{CFO}}, \mathrm{REM}_{\mathrm{RSD}}$, and $\mathrm{REM}_{\mathrm{DE}}$. $\mathrm{REM}_{\mathrm{CFO}}, \mathrm{REM}_{\mathrm{RSD}}$, and $\mathrm{REM}_{\mathrm{DE}}$ are estimated residuals from the formula 2, 3, and 4, respectively. AEM is accrual earnings management which is estimated residuals from formula 1.

Table 4. Descriptive Data of Firm Characteristics

\begin{tabular}{llccc}
\hline \multicolumn{1}{c}{ Variables } & N & Min. & Max. & Mean \\
\hline Audit Quality & 63 & 0.000 & 1.000 & \\
Financial Health & 63 & -1.290 & 2.080 & 0.100 \\
Market Share & 63 & 0.010 & 0.380 & 0.096 \\
Institutional Own. Beg. & 63 & 0.770 & 1.000 & 0.978 \\
ROA & 63 & -0.169 & 0.023 & -0.003 \\
Size & 63 & 12.110 & 13.990 & 12.009 \\
Leverage & 63 & 0.060 & 0.320 & 0.167 \\
\hline
\end{tabular}

is a reduction of discretionary expenses. Discretionary expense is less than normal condition which results in upward earnings management. However, the mean of the total value of REM shows positive number. It means that generally Islamic banks do upward REM or increase earnings from real activities which shows that real activities can support the earnings.

Meanwhile, the negative mean value of AEM indicates that Islamic banks tend do downward AEM. It signifies that Islamic banks exclude the application of accruals to increase earnings. Accruals are difficult to manage that may be due to control mechanisms such as applying accounting principles consistently or determining accounting judgement carefully. The different mean values between REM (positive, upward earnings management) and AEM (negative, downward earnings management) are in accordance with the first finding that AEM substitutes REM. When REM is likely upward the earnings, then AEM is not used as it shows downward direction. 
Table 5. Correlation between Real Earnings Management (REM) and Accrual-based Earnings Management (AEM)

\begin{tabular}{c|ccccc}
\hline & $\mathbf{R E M}_{\text {CFO }}$ & $\mathbf{R E M}_{\mathbf{R S D}}$ & $\mathbf{R E M}_{\mathbf{D E}}$ & $\mathbf{R E M}$ & $\mathbf{A E M}$ \\
\hline $\mathrm{REM}_{\mathrm{CFO}}$ & & 0.318 & 0.198 & 0.892 & -0.932 \\
& & 0.011 & 0.120 & 0.000 & 0.000 \\
$\mathrm{REM}_{\mathrm{RSD}}$ & & & & & \\
& & & 0.019 & 0.384 & -0.325 \\
& & 0.884 & 0.002 & 0.009 \\
$\mathrm{REM}_{\mathrm{DE}}$ & & & & 0.602 & 0.087 \\
& & & & 0.000 & 0.498 \\
$\mathrm{REM}$ & & & & & -0.714 \\
& & & & & \\
\hline
\end{tabular}

Table 4 presents the descriptive data of firm characteristics. More than a half of Islamic banks are audited by accounting firms that are affiliated with Big- 4 which shows high audit quality. The positive mean value of financial health amounted to 0.100 indicates that most of the Islamic banks have more cash flow than total debts. It means that Islamic banks have cash surplus after particular portion for paying the debts. The mean value of the market share of 0.096 shows that average market share of each bank from the total of 11 Islamic banks is around 9\%. The mean value of institutional ownership of 0.978 shows that almost all of Islamic banks are owned by the institutions, not owned by the individual. The majority shareholders of almost Islamic banks are the conventional parent company of the banks, except Bank Muamalat Indonesia.

The negative mean value of ROA amounted to -0.003 indicates that some Islamic banks generate a net loss in some financial period. The minimum value of the size of 12.110 and the maximum of 13.990 show all banks have almost the same size in general. The bank that has the smallest size is Bank Victoria Syariah and the biggest one is Bank Syariah Mandiri. The mean value of leverage of 0.167 means that total liabilities is about $16.7 \%$ of the total assets in average.

\section{Correlation and Regression Test}

Correlation between REM and AEM is presented on Table 5. Regression of relative costs on REM and AEM is shown on Table 6.

Based on Table 5, a probability of 0.011 indicates that $\mathrm{REM}_{\mathrm{CFO}}$ is positively correlated with $\mathrm{REM}_{\mathrm{RSD}}$, but the coefficient of 0.318 shows weak correlation. It means that REM is done through generating operation revenue more and reducing distributed revenue sharing beyond the normal activities simultaneously. $\mathrm{REM}_{\mathrm{CFO}}$ and $\mathrm{REM}_{\mathrm{RSD}}$ are not correlated with $\mathrm{REM}_{\mathrm{DE}}$ which mean the Islamic banks exclude discretionary expenses in doing REM. It can be due to difficulties to reduce discretionary expenses in an abnormal way. REM $\mathrm{CFO}_{1}, \mathrm{REM}_{\mathrm{RSD}}$, and $\mathrm{REM}_{\mathrm{PE}}$ are positively correlated with total REM due to REM is a total amount of REM ${ }_{C F O}, \mathrm{REM}_{\mathrm{RSD}}$, and REM $\mathrm{DE}_{\mathrm{DE}}$. Therefore, REM TFO $_{\text {, }}$ $\mathrm{REM}_{\mathrm{RSD}}$, and REM ${ }_{\mathrm{DE}}$ will be definitely correlated with REM. REM ${ }_{\mathrm{CFO}}$ has very strong correlation with REM as indicated by the coefficient of 0.892 . It signifies that REM is mostly conducted through $\mathrm{REM}_{\mathrm{CFO}}$ or abnormal cash flow from operations.

$\mathrm{REM}_{\mathrm{CFO}}$ and REM $\mathrm{RSP}_{\text {are negatively correlated with } \mathrm{AEM} \text {. REM }}$ is very strongly correlated with AEM as shown by the coefficient of -0.932 , but REM $_{\mathrm{RSD}}$ is weakly correlated with AEM as shown by the coefficient of -0.325 . This result is consistent with the total REM that is also negatively correlated with AEM as shown by coefficient of -0.714 . Meanwhile, $\mathrm{REM}_{\mathrm{PE}}$ is not correlated with AEM. It shows that discretionary expenses are not the factor affecting or being affected by AEM. This result is consistent with no correlation between $\mathrm{REM}_{\mathrm{DE}}$ and other REM proxies as explained in the previous paragraph whereas Islamic banks do not manipulate discretionary expenses in abnormal way.

These findings are in accordance with Zang (2012), Joosten (2012), Badertscher (2011), Chung et al. (2012), Cohen et al. (2008) that REM negatively affects AEM. It confirms the hypothesis that the level of AEM will be raised based on the results of REM done through the financial period. The reason of manager chooses one or another is based on the order of earnings management can occur (Badertscher, 2011), as stated above that REM is conducted before AEM. This negative correlation is in accordance with prospect theory. When company face loss or negative earnings as the results of REM, it reflects that managers have no opportunity to manipulate earnings through real activities. Afterwards, managers will use discretion and judgment to manipulate earnings upward in order to 
Table 6. The Trade-Off between Real Earnings Management (REM) and Accrual-based Earnings Management (AEM)

\begin{tabular}{|c|c|c|c|c|c|c|}
\hline & Hypothesis & Coefficient & $\begin{array}{c}\text { REM } \\
\text { Equation } \\
\text { (Prob.) }\end{array}$ & Hypothesis & Coefficient & $\begin{array}{c}\text { AEM } \\
\text { Equation } \\
\text { (Prob.) }\end{array}$ \\
\hline \multicolumn{7}{|l|}{ Costs of AEM } \\
\hline Audit Quality & + & 0.022 & 0.427 & - & 0.004 & 0.869 \\
\hline Financial Health & + & -0.027 & 0.278 & - & 0.039 & 0.061 \\
\hline Market Share & + & 0.285 & 0.060 & - & -0.263 & 0.034 \\
\hline \multicolumn{7}{|l|}{ Cost of REM } \\
\hline $\begin{array}{l}\text { Institutional Own- } \\
\text { ership }\end{array}$ & - & 0.482 & 0.026 & + & -0.353 & 0.045 \\
\hline \multicolumn{7}{|l|}{ Control Variables } \\
\hline ROA & & 0.952 & 0.019 & & 0.644 & 0.051 \\
\hline Size & & -0.044 & 0.009 & & 0.031 & 0.024 \\
\hline Leverage & & 0.430 & 0.043 & & -0.218 & 0.203 \\
\hline $\begin{array}{l}\text { F-statistics } \\
\text { Adj. } \mathrm{R}^{2}\end{array}$ & H3 & 0.215 & & $\begin{array}{l}\mathrm{H} 2 \mathrm{a}, \mathrm{H} 2 \mathrm{~b} \\
\mathrm{H} 2 \mathrm{c}, \mathrm{H} 2 \mathrm{~d}\end{array}$ & 0.179 & \\
\hline
\end{tabular}

gain additional earnings through AEM and report has positive income (Subekti, 2012). Otherwise, managers will decrease the AEM if company can generate income as the results of REM.

As prospect theory states, the substitution between REM and AEM is performed to achieve target (Tang et al., 2016: Christiawan \& Narsa, 2020). The income is not too high, but management is just likely to meet the specific target, such as above prior year's earning, change from negative to positive income or smooth the income. Earnings that are below the target will increase upward, whereas earnings that are far above from the target could be reduced so that future threshold is possible to achieve (Pududu \& Villiers, 2016). Smoothing earnings seems less risker than volatile earnings (Graham et al., 2005). Regardless, it is impossible for Islamic banks to detach themselves from this threshold mechanism and desire to attain profit target (Hamdi \& Zarai, 2012).

The impact of costs on REM and AEM is shown on Table 6. Audit quality does not affect AEM and REM. Audited by Big-4 accounting firms still elicit AEM behavior of Islamic Banks. The finding is different with the previous studies that audit quality can constraint managers' ability to do AEM (Cohen \& Zarowin, 2010; Burnett et al., 2012; Barton \& Simko, 2002) as Big-4 accounting firms can provide better audit quality.

Financial health does not affect AEM and REM. This finding is inconsistent with previous findings that financial health positively affects REM. Healthy banks have good financial performance through real activities, while unhealthy banks fail to meet the operation target, and have lack opportunity to manipulate real activities so managers are predicted to concern on AEM using financial reporting (Zang, 2012). This finding indicates that financial health does not determine whether banks will engage in REM and AEM. Both healthy and less healthy banks can engage in REM and AEM without any particular pattern.

Market share negatively affects AEM which confirms the hypothesis. Islamic banks which dominate the market as shown by the operating revenue will do less AEM because they have competitive advantages and economic benefits derived from customers (Zang, 2012). However, the result also shows that banks with higher market normally operate without manipulating earnings. The market share through normal real activities can be obtained by Islamic banks as shown by no impact of market share on REM.

Institutional ownership is found to have impact both on REM and AEM, but the result is in different direction with the hypothesis. The hypothesis states that institutional ownership should negatively affect REM because institutional investors are involved in long-term and strategic decision making so that will avoid real manipulation with short term target (Tanjung et al., 2015; Kazemian \& Sanusi, 2015; Zang, 2012). However, the result shows institutional ownership pushes upward REM and decreases AEM. Institutions even encourage banks to maximize the operating revenue obtained from real activities or channeling the funds and manage the sharing distribution beyond the normal activities as the previous results. 
Based on the explanation above, audit quality, and financial health are not cost that suppress AEM. Related to market share, the result confirms that market share can be a cost that limit management to employ AEM. However, the role of institutional ownership shows different direction with Zang (2012). The institutional ownership is a control mechanism to decrease agency conflict by monitoring the AEM, not by the REM as predicted.

ROA positively affects REM. It means that ROA affects managers' incentives to apply REM with the aim to achieve the income target (Hamdi \& Zarai, 2012). Size negatively affects REM and positively affects AEM. Size shows more capabilities (Alves et al., 2016), so that it will decrease REM. Meanwhile, leverage positively affects REM. Higher ratio of liabilities indicates higher debts or more funds collected from depositors which require more cost (Ahmed et al., 2018) to replenish the debts and distribute revenue sharing to depositors. It will push banks to do REM to cover the costs.

In general, the impact of banks' characteristics on REM and AEM in Islamic banks is similar with conventional banks. Islamic banks with Islamic values also conduct earnings management to smooth earnings. The difference is Islamic banks do activities based on aqad permissible by sharia. Islamic banks derive and channel funds through Islamic transaction, and provide returns for depositors in the form of revenue sharing. The Islamic transaction also turns out to be a media to do earnings management.

\section{CONGLUSION}

There are 2 objective of this study which are: 1) to observe the relationship between REM and AEM based on prospect theory, and 2) to find which control mechanisms among governance and capital ability of the banks that can control REM or AEM based on agency theory. Islamic banks in Indonesia is found to do REM through generating operation revenue and reducing distributed revenue sharing beyond the normal activities and not managing discretionary expenses. REM is found negatively affecting AEM whereas Islamic banks do upward REM and downward AEM. If by doing REM have attained the income target, managers avoid employing the AEM as stated by the prospect theory.

Audit quality and financial health are not cost that decrease REM and AEM. Market share negatively affects AEM which shows that domination of the market indicates good performance through real activities that results in lower AEM. Institutional ownership is found to have impact both on REM and AEM, but contrary to the hypothesis. Institutional ownership encourages banks to maximize the operating revenue through upward REM, and it then decreases AEM. These results show that both market share and institutional ownership are mechanisms to control AEM referring to agency theory.

The outcome of this study can provide additional explanation related to the specific technique of earnings management occurring in Islamic Banks. Funders may gain the reliability of earnings whether the incentives of earnings management are strong or weak. For standard setters, the high AEM through accounting discretion might need a restriction. Banks' financial statements with high accruals and large difference between cash flows and profit are indication of earnings management (Riwayati et al., 2015).

Limitation of the study is variable costs tested are based on the previous studies. This study tests variable costs from bank characteristics such as financial health, market share, and governance aspects such as audit quality and institutional ownership. Suggestion for further study is adding variable costs like other banks' characteristics and governance, financial reporting practice related to standards used or capital market incentives in order to provide more comprehensive results. Besides, it needs to observe the pattern of earnings management based on specific conditions, not in an aggregate way. Different growth rate of bank or a change of economics climate and policy related to capital market or standards, may result in different findings. Further research may also compare the pattern between Islamic and conventional bank contexts to observe whether there is difference earnings management among them or among countries.

\section{REFERENCES}

Agarwal, S., Chomsisengphet, S., Liu, C., \& Rhee, S. G. (2007). Earnings Management Behaviors Under Different Economic Environments: Evidence from Japanese Banks. International Review of Economics and Finance, 16(3), 429-443. doi:10.1016/j.iref.2005.08.003.

Ahmed, F., Awais, I., \& Kashif, M. (2018). Financial Leverage and Firms' Performance: Empirical Evidence from KSE-100 Index. Etikonomi, 171), 45-56. doi: 10.15408/etk.v17i16102. 
Alves, M. F. R., Salvini, J. T. S., Bansi, A. C., Neto, E. G., \& Galina, S. V. R. (2016). Does the Size Matter for Dynamics Capabilities? A Study on Absorptive Capacity. Journal of Technology Management \& Innovation, 11(3). doi:10.4067/S0718-27242016000300010.

Badertscher, B. A. (2011). Overvaluation and The Choice of Alternative Earnings Management Mechanisms. The Accounting Review, 86(5), 1491-1518. doi:10.2308/accr-10092.

Barth, M. E., Biscarri, J. G., Kasznik, R., \& López-Espinosa, G. (2017). Bank Earnings and Regulatory Capital Management Using Available for Sale Securities. Review of Accounting Studies, 22(4), 1761-1792. doi: 10.2139/ssrn.2448482.

Barton, J., \& Simko, P. J. (2002). The Balance Sheet as an Earnings Management Constraint. The Accounting Review, 77 (supplement), 1-27. doi:10.2139/ssrn.320641.

Beatty, A. L., Ke, B., \& Petroni, K. R. (2002). Earnings Management to Avoid Earnings Declines Across Publicly and Privately Held Banks. The Accounting Review, 77(3), 547-570. doi:10.2308/ accr.2002.77.3.547.

Beaver, W. H. (1966). Financial Ratios as Predictors of Failure. Journal of Accounting Research, Vol. 4 (Empirical Research in Accounting: Selected Studies), 71-111. doi:10.2307/2490171.

Bjurman, A. \& Weihagen, E. (2013). How Reliabel are Earnings.? Master Degree Project, Umea School of Business.

Bowman, E. H. (1980). A Risk/Return Paradox for Strategic Management. Sloan Management Review, 21(3), 17-31. doi:10.2139/ssrn.1014325.

Burnett, B. M., Cripe, B. M., Martin, G. W., \& McAllister, B. P. (2012). Audit Quality and The Trade-Off Between Accretive Stock Repurchases and Accrual-Based Earnings Management. The Accounting Review, 876), 1861-1884. doi:10.2308/accr-50230.

Chou, Y. Y. \& Chan, M. L. (2018). The Impact of CEO Characteristics on Real Earnings Management: Evidence from The US Banking Industry. Journal of Applied Finance \& Banking; 8(2), 17-44.

Christiawan, Y.J. \& Narsa, I. M. (2020). Earnings Management through Foreign Currency Transactions on Companies Listed on Indonesia Stock Exchange. SHS Web of Conference, 76, 1-12.

Chung, R. Y.-M., Bao, B.-H., Niu, Y., \& Wei, S. (2012). Real and Accrual Earnings Management Around IPOS: Evidence from US Companies Author. In Accounting and Finance Association of Australia and New Zealand Conference (AFAANZ). Melbourne.

Cohen, D. A. \& Zarowin, P. (2010). Accrual-Based and Real Earnings Management Activities around Seasoned Equity Offerings. Journal of Accounting and Economics, 50(1), 2-19. doi:10.1016/j. jacceco.2010.01.002.

Cohen, D. A., Dey, A., \& Lys, T. Z. (2008). Real and Accrual-Based Earnings Management in The Pre- and Post-Sarbanes-Oxley Periods. The Accounting Review, 83(3), 757-787. doi:10.2139/ ssrn.813088.

Degeorge, F., Patel, J., \& Zeckhauser, R. (1999). Earnings Management to Exceed Thresholds. The Journal of Business, 72(1), 1-33. doi:10.1086/209601.

Eisele, A. (2012). Target Shooting? Benchmark-Driven Earnings Management in Germany. University of St. Gallen, St. Gallen. https://www1.unisg.ch/www/edis.nsf/SysLkpByIdentifier/4009/\$FILE/ dis4009.pdf.

Ewert, R. \& Wagenhofer, A. (2005). Economic Effects of Tightening Accounting Standards to Restrict Earnings Management. The Accounting Review, 80(4), 1101-1124. doi:10.2308/ accr.2005.80.4.1101.

Farook, S., Hassan, M. K., \& Clinch, G. (2014). Islamic Bank Incentives and Discretionary Loan Loss Provisions. Pacific Basin Finance Journal, 28, 152-174. doi:10.1016/j.pacfin.2013.12.006.

Fiegenbaum, A. (1990). Prospect Theory and The Risk-Return Association: An Empirical Examination in 85 Industries. Journal of Economic Behavior and Organization, 14(2), 187-203. doi:10.1016/0167-2681(90)90074-N. 
Graham, J. R., Harvey, C. R., \& Rajgopal, S. (2005). The Economic Implications of Corporate Financial Reporting. Journal of Accounting and Economics, 4O(1-3), 3-73. doi:10.1016/j. jacceco.2005.01.002.

Gunny, K. A. (2010). The Relation Between Earnings Management Using Real Activities Manipulation and Future Performance: Evidence from Meeting Earnings Benchmarks. Contemporary Accounting Research, 27(3), 855-888. doi:10.1111/j.1911-3846.2010.01029.

Hamdi, F. M., \& Zarai, M. A. (2012). Earnings Management to Avoid Earnings Decreases and Losses: Empirical Evidence from Islamic Banking Industry. Research Journal of Finance and Accounting, 3(3), 88-106.

Hamdi, F. M., \& Zarai, M. A. (2013). Earnings Management and Investment Accounts Holders Interests in Islamic Banking Institutions. International Journal of Business and Management Invention, 2(12), 22-35.

Hermiyetti \& Manik, E. N. (2012). The Influence of Good Corporate Governance Mechanism on Earnings Management: Empirical Study in Indonesian Stock Exchange Listed Company for Periods of 2006-2010. Indonesian Capital Market Review, V1), 52-63. doi:10.21002/icmr. v5i1.1583.

Ibrahim, S., Xu, L., \& Rogers, G. (2011). Real and Accrual-Based Earnings Management and Its Legal Consequences: Evidence from Seasoned Equity Offerings. Accounting Research Journal, 24(1), 50-78. doi:10.1108/10309611111148779.

Jafarpour, M. \& Soumehsaraei, B. G. (2013). Investigate Real Earning Management and Accounting Earning Management from The Perspective of Income Smoothing. International Journal of Innovative Research in Science, Engineering and Technology, 212), 7256-7263.

Joosten, C. (2012). Real Earnings Management and Accrual-Based Earnings Management as Substitutes. Thesis. Tilburg University. Netherlands.

Kahneman, A. \& Tversky, A. (1979). Prospect Theory: An Analysis of Decision Under Risk. Econometrica, 472), 263-291. doi:10.2307/1914185.

Kazemian, S. \& Sanusi, Z. M. (2015). Earnings Management and Ownership Structure. Procedia Economics and Finance, 31, 618-624. doi:10.1016/S2212-5671(15)01149-1.

Koonce, L. L. \& Mercer, M. (2005). Using Psychology Theories in Archival Financial Accounting Research. McCombs Research Paper Series. doi:10.2139/ssrn.311105.

Kothari, S. P., Mizik, N., \& Roychowdhury, S. (2016). Managing for The Moment: The Role of Earnings Management via Real Activities Versus Accruals in SEO Valuation. The Accounting Review, 91(2), 559-586. doi:10.2139/ssrn.1982826.

Li, L. \& Hwang, N. R. (2017). Prospect Theory and Earnings Manipulation: Examination of The Non-Uniform Relationship Between Earnings Manipulation and Stock Returns Using Quantile Regression. Working Papers in Economics, 17(25), University of Waikato.

Ozili, P. K. (2017). Bank Earnings Management and Income Smoothing Using Commission and Fee Income: A European context. International Journal of Managerial Finance, 13(4), 419-439. doi:10.1108/IJMF-11-2016-0213.

Ozili, P. K. \& Outa, E. (2019). Bank Earnings Management Using Commission and Fee Income: The Role of Investor Protection and Economic Fluctuation. Journal of Applied Accounting Research, 20(2), 172-189. doi:10.1108/JAAR-02-2018-0030.

Pududu, M. L. \& Villiers, C. D. (2016). Earnings Management through Loss Avoidance: Does South Africa Have a Good Story to Tell?. South African Journal of Economic and Management Sciences (SAJEM), 19(1), 18-34. doi:10.17159/2222-3436/2016/v19n1a2.

Quttainah, M. A., Song, L., \& Wu, Q. (2011). Do Islamic Banks Employ Less Earnings Management?. Politics and Economic Development Economic Research Forum (ERF) 17th Annual Conference. Beldibi. doi:10.5465/ambpp.2012.10270abstract. 
Rettab, B., Kashani, H., Obay, L., \& Rao, A. (2010). Impact of Market Power and Efficiency on Performance of Banks in The Gulf Cooperation Council Countries. International Research Journal of Finance and Economics, (50), 190-203.

Riwayati, H. E., Markonah, \& Siladjaja, M. (2016). Implementation of Corporate Governance Influence to Earnings Management. Procedia Social and Behavioral Sciences, 219, 632-638.

Roychowdhury, S. (2006). Earnings Management through Real Activities Manipulation. Journal of Accounting and Economics, 42(3), 335-370. doi:10.1016/j.jacceco.2006.01.002.

Saringat, S. M., Haron, R., \& Tahir, H. H. M. (2013). Income Smoothing and Islam: An Evidence From Malaysian Shariah Compliant Companies. International Journal of Social Science and Humanity, 3(2), 160-162. doi:10.7763/ijssh.2013.v3.218.

Scott, W. R. (2012). Financial Accounting Theory (6th ed.). Toronto: Prentice Hall Canada.

Shen, C. \& Chih, H. (2005). Investor Protection, Prospect Theory, and Earnings Management: An International Comparison of The Banking Industry. Journal of Banking and Finance, 29(10), 2675-2697. doi:0.1016/j.jbankfin.2004.10.004.

Srivastava, A. (2019). Improving the Measures of Real Earnings Management. Review of Accounting Studies, 24, 1277-1316. doi:10.1007/s11142-019-09505-z.

Stolowy, H., \& Breton, G. (2000). A Framework for The Classification of Accounts Manipulations. HEC Accounting \& Management Control Working Paper No. 708/2000. doi:10.2139/ssrn.263290.

Subekti, I. (2012). Accrual and Real Earnings Management: One of The Perspectives of Prospect Theory. Journal of Economics, Business, and Accountancy Ventura, 15(3), 443-456. doi:10.14414/ jebav.v1513.113.

Surifah. (2014). Expropriation Risk through Real Earnings Management on Islamic Banking. Indonesian Capital Market Review, 72), 74-91. doi:10.21002/icmr.v7i2.5137.

Surifah. (2017). The Role of Corporate Governance in The Effect Earnings Management Has on Firm Value. Journal of Indonesian Economy and Business, 32(1), 51-69. doi:10.22146/jieb.12793.

Tang, Q., Chen, H., \& Lin, Z. (2016). How to Measure Country-Level Financial Reporting Quality?. Journal of Financial Reporting and Accounting, 14(2), 230-265. doi:10.1108/JFRA-09-2014-0073.

Tanjung, M., Sucherly, Sutisna, \& Sudarsono, R. (2015). The Role of Good Corporate Governance in Minimizing Earnings Management to Increase Value of Firm. International Journal of Scientific \& Technology Research, 4(9), 21-27.

Vladu, A. B. (2015). Managerial Preferences between Accrual-Based versus Real Earnings Management. Hyperion International Journal of Econophysics \& New Economy, 8(2), 409-417.

Wasiuzzaman, S. (2018). Industry Characteristics and Earnings Management: A Study of Malaysian Industries. International Journal of Emerging Markets, 13(5), 837-854. doi:10.1108/ IJAIM-06-2015-0031.

Zang, A. Y. (2012). Evidence on The Trade-Off Between Real Activities Manipulation and AccrualBased Earnings Management. The Accounting Review, 87(2), 675-703. doi:10.2308/accr-10196. 
Halaman ini sengaja dibiarkan kosong 